\title{
Standpunt van iap (Interacademy Panel) oor evolusie
}

\section{INLEIDEND}

Die onderrrig van evolusie vorm tans deel van die onderwyskurrikulum in Suid-Afrika en dit is wenslik dat ouers, leerders en onderwysers kennis sal neem van 'n wye verskeidenheid van standpunte oor evolusie ten einde 'n eie, ingeligte mening te kan vorm. Goeie insig oor die onderwerp en die vorming van ' $\mathrm{n}$ verantwoordbare eie standpunt is egter afhanklik van 'n deeglike en indringende kennis van die onderliggende dissiplines waarop so 'n standpunt moet berus. In soverre as wat die verskynsel van evolusie binne die kader van die natuurwetenskappe val, is dit noodsaaklik dat daar kennis geneem word van die leidinggewende standpunt wat deur 'n groot persentasie van natuurwetenskaplikes onderskryf word op grond van hulle kennis van die betrokke dissiplines.

Die standpunt van die Interakademiese Paneel wat deur 68 wetenskapakademies uit verskeie wêrelddele onderskryf word, word met hulle goedkeuring hieronder weergegee as voorbeeld van so 'n standpuntstelling. Dit beteken nie dat dit die enigste of mees korrekte standpunt oor die onderwerp is nie, maar behoort nie deur studente van die natuurwetenskappe buite rekening gelaat te word in die formulering van 'n eie standpunt nie - Die Redaksie verwelkom alternatiewe standpunte omtrent hierdie onderwerp.

\section{STANDPUNT VAN IAP}

Ons, die ondergetekende Wetenskapakademies, het kennis geneem dat daar in verskeie wêrelddele, binne wetenskapkursusse wat in sekere openbare opvoedingstelsels onderrig word, wetenskaplike getuienis, data en toetsbare teorieë omtrent die oorsprong en evolusie van lewe op die Aarde, verberg, ontken of verwar word met teorieë wat nie wetenskaplik toetsbaar is nie. Ons versoek dat besluitnemers, onderwysers en ouers alle kinders in die metodes en ontdekkings van die wetenskap sal onderrig en 'n begrip van die natuurwetenskap sal bevorder. Kennis van die natuurlike wêreld waarin hulle lewe, bemagtig mense om in hul menslike behoeftes te kan voldoen en om die planeet te beskerm.

Ons stem saam dat die volgende feite omtrent die oorsprong en evolusie van die Aarde en lewe op hierdie planeet op getuienis berus en dat dit deur talryke waarnemings en onafhanklike eksperimentele resultate bevestig is deur menige wetenskaplike dissiplines. Self al is daar steeds baie onbeantwoorde vrae omtrent die presiese besonderhede van evolusionêre verandering, is hierdie resultate nog nooit deur wetenskaplike gegewens verkeerd bewys nie:

1. Ons planeet Aarde is ongeveer 4.5 biljoen jaar gelede gevorm binne ' $n$ heelal wat tot sy huidige konfigurasie evolueer het vir sowat 11 tot 15 biljoen jaar.

2. Sedert sy totstandkoming, het die Aarde - sy geologie en omgewings - onder die invloed van talryke fisiese en chemiese kragte verander, en hierdie verandering duur steeds voort.

3. Lewe op Aarde het ten minste 2.5 biljoen jaar gelede ontstaan. Die evolusie van fotosinterende organismes kort daarna, het vanaf ten minste 2 biljoen jaar gelede die stadige transformasie van die atmosfeer moontlik gemaak tot 'n atmosfeer wat aansienlike hoeveelhede suurstof bevat. Bykomend tot die vrystelling van suurstof wat ons inasem, is die proses van fotosintese die fundamentele bron van vasgelegde energie en voedsel waarvan menslike lewe op die planeet afhanklik is. 
4. Sedert die eerste verskyning van lewe op die planeet Aarde, het dit verskillende vorms aangeneem wat voortgaan om te evolueer op wyses wat met toenemende akkuraatheid deur paleontologie en die moderne biologiese en biochemiese wetenskappe, onafhanklik van mekaar, beskryf word. Ooreenkomste in die struktuur van die genetiese kodes van alle hedendaagse lewende organismes, insluitend mense, wys duidelik op hulle gemeenskaplike primordiale oorsprong.

Ons onderskryf ook die volgende standpunt oor die aard van wetenskap met betrekking tot die onderrig van evolusie, en meer algemeen, enige gebied van wetenskaplike kennis:

Wetenskaplike kennis kom tot stand deur 'n metode van ondersoek van die natuur binne die heelal, wat suksesvol uitgevoer is met belangrike gevolge. Wetenskap fokus op (i) waarneming van die natuurlike wêreld, en (ii) die formulering van toetsbare en weerlegbare hipoteses om tot dieper verklarings te kom vir waarneembare fenomene. Wanneer getuienis genoegsame oortuiging bied, word wetenskaplike teorieë ontwikkel wat rekenskap van hierdie getuienis gee en dit verklaar, asook voorspel wat die waarskynlike struktuur of proses van tot-nog-toe nie-waargenome verskynsels sal wees.

Menslike begrip van waarde en doel lê buite die sfeer van die natuurwetenskap. 'n Aantal komponente - wetenskaplik, sosiaal, filosofies, godsdienstig, kultureel en polities - dra egter hiertoe by. Hierdie verskillende velde is wedersydse oorweging/begrip aan mekaar verskuldig, terwyl hulle ook ten volle bewus moet wees van hulle eie aktiwiteitsfere en beperkings.

Alhoewel huidige beperkings erken word, is die wetenskap steeds oop en onderworpe aan regstellings en uitbreiding namate nuwe teoretiese en empiriese insigte na vore tree.

Onderskryf deur:

1. Albanian Academy of Sciences

2. National Academy of Exact, Physical and Natural Sciences, Argentina

3. Australian Academy of Science

4. Austrian Academy of Sciences

5. Bangladesh Academy of Sciences

6. The Royal Academies for Science and the Arts of Belgium

7. Academy of Sciences and Arts of Bosnia and Herzegovina

8. Brazilian Academy of Sciences

9. Bulgarian Academy of Sciences

10. RSC: The Academies of Arts, Humanities and Sciences of Canada

11. Academia Chilena de Ciencias

12. Chinese Academy of Sciences

13. Academia Sinica, China, Taiwan

14. Colombian Academy of Exact, Physical and Natural Sciences

15. Croatian Academy of Arts and Sciences

16. Cuban Academy of Sciences

17. Academy of Sciences of the Czech Republic
18. Royal Danish Academy of Sciences and Letters

19. Academy of Scientific Research and Techonolgy, Egypt

20. Académie des Sciences, France

21. Union of German Academies of Sciences and Humanities

22. The Academy of Athens, Greece

23. Hungarian Academy of Sciences

24. Indian National Science Academy

25. Indonesian Academy of Sciences

26. Academy of Sciences of the Islamic Republic of Iran

27. Royal Irish Academy

28. Israel Academy of Sciences and Humanities

29. Accademia Nazionale dei Lincei, Italy

30. Science Council of Japan

31. Kenya National Academy of Sciences

32. National Academy of Sciences of the Kyrgyz Republic

33. Latvian Academy of Sciences

34. Lithuanian Academy of Sciences

35. Macedonian Academy of Sciences and Arts 
36. Academia Mexicana de Ciencias

37. Mongolian Academy of Sciences

38. Academy of the Kingdom of Morocco

39. The Royal Netherlands Academy of Arts and Sciences

40. Academy Council of the Royal Society of New Zealand

41. Nigerian Academy of Sciences

42. Pakistan Academy of Sciences

43. Palestine Academy for Science and Technology

44. Academia Nacional de Ciencias del Peru

45. National Academy of Science and Technology, The Philippines

46. Polish Academy of Sciences

47. Académia des Sciences et Techniques du Sénégal

48. Serbian Academy of Sciences and Arts

49. Singapore National Academy of Sciences

50. Slovak Academy of Sciences

51. Slovenian Academy of Sciences and Arts

52. Academy of Science of South Africa
53. Royal Academy of Exact, Physical and Natural Sciences of Spain

54. National Academy of Sciences, Sri Lanka

55. Royal Swedish Academy of Sciences

56. Council of the Swiss Scientific Academies

57. Academy of Sciences, Republic of Tajikistan

58. The Caribbean Academy of Sciences

59. Turkish Academy of Sciences

60. The Uganda National Academy of Sciences

61. The Royal Society, UK

62. US National Academy of Sciences

63. Uzbekistan Academy of Sciences

64. Academia de Ciencias Físicas, Matemáticas y Naturales de Venezuela

65. Zimbabwe Academy of Sciences

66. African Academy of Sciences

67. The Academy of Sciences for the Developing World (TWAS)

68. The Executive Board of the International Council for Science (ICSU) 